\title{
PELATIHAN PEMBUATAN MEDIA PEMBELAJARAN BERBASIS KOMPUTER DI SEKOLAH MENENGAH PERTAMA KECAMATAN RANTAU BADAUH BARITO KUALA
}

\author{
Ahmad Hendrawan ${ }^{1}$, Rabiatul Adawiyah ${ }^{2}$, M. Syafwansyah Effendi ${ }^{3}$, M. Khafidz Arifin ${ }^{4}$ \\ Jurusan Teknik Mesin Program Studi Alat Berat Politeknik Negeri Banjarmasin ${ }^{1234}$ \\ ahendrawan@poliban.ac.id ${ }^{1}$ \\ rabiatulpoltek@yahoo.com ${ }^{2}$ \\ $\underline{\text { msayfwansyah@poliban.ac.id }}^{3}$ \\ khafidz@poliban.ac.id ${ }^{4}$
}

\begin{abstract}
Rantau Badauh Subdistrict is located in Barito Kuala Regency which is located around $25 \mathrm{~km}$ from the capital of Barito Kuala Regency and around $20 \mathrm{~km}$ from the Capital City of South Kalimantan (Banjarmasin). The village area consists of paddy fields, yards, swamps, rivers, and forests.

Teachers as the spearhead in the world of education, are required to always be responsive and sensitive to the various innovations that occur around them, teachers must be able to follow the rapid development of science, technology and information.

Most teachers have not used computer technology for the learning process, for example to create simple computer-based learning media or to administer learning activities.

Training activities are carried out using survey methods, lectures, training practices and discussion - consultation. The survey was conducted by distributing a 'user need assessment' questionnaire to school teachers to get the data of the type and needs of teachers in mastering the most needed computer skills. Mastery of computer skills is categorized in supporting the learning process, making learning media.

The output target of this activity is to Improve the Teacher's Ability in Developing Computer Based Learning Media.
\end{abstract}

Keywords: Teacher, Learning Media, Computer Based

\begin{abstract}
ABSTRAK
Kecamatan Rantau Badauh terletak di Kabupaten Barito Kuala yang terletak disekitar 25 km dari ibukota Kabupaten Barito Kuala dan sekitar 20 km dari Ibu Kota Kalimantan Selatan (Banjarmasin). Wilayah desa tersebut terdiri dari lahan Persawahan, Pekarangan, Rawa-rawa, Sungai dan Hutan.

Guru sebagai ujung tombak dalam dunia pendidikan, dituntut untuk senantiasa tanggap dan peka terhadap berbagai pembaharuan yang terjadi di sekelilingnya, guru harus mampu mengikuti pesatnya perkembangan ilmu pengetahuan, teknologi dan informasi.
\end{abstract}


Sebagian besar guru belum memanfaatkan teknologi komputer untuk proses pembelajaran, misal untuk membuat media pembelajaran sederhana berbasis komputer ataupun untuk pengadministrasian kegiatan pembelajaran.

Kegiatan pelatihan yang diselenggarakan menggunakan metode survei, ceramah, praktek pelatihan dan diskusi - konsultasi. Survei dilakukan dengan menyebarkan angket 'user need assesment' kepada guru sekolah untuk mendapatkan data jenis dan kebutuhan guru dalam penguasaan ketrampilan komputer yang paling dibutuhkan. Penguasaan ketrampilan komputer dikategorikan dalam pendukung proses pembelajaran, pembuatan media pembelajaran.

Target luaran dari kegiatan ini adalah Meningkatkan Kemampuan Guru Dalam Pengembangan Media Pembelajaran Berbasisi Komputer.

Kata Kunci : Guru, Media Pembelajaran, Berbasis Komputer

\section{PENDAHULUAN}

\section{Analisa Situasi}

Kecamatan Rantau Badauh terletak di Kabupaten Barito Kuala yang terletak disekitar $25 \mathrm{~km}$ dari ibukota Kabupaten Barito Kuala dan sekitar $20 \mathrm{~km}$ dari Ibu Kota Kalimantan Selatan (Banjarmasin). Wilayah desa tersebut terdiri dari lahan Persawahan, Pekarangan, Rawa-rawa, Sungai, Handil dan Hutan.

Dalam intraksi sosial dimasyarakat, penduduk Kecamatan Rantau Badauh menggunakan bahasa Indonesia, dan bahasa Banjar sebagai bahasa sehari-hari

Adapun mata pencaharian penduduk masyarakat kecamatan Rantau Badauh beraneka ragam yaitu seperti : Petani, Peternak, Pedagang, Pengusaha, Buruh, PNS dan Pegawai Swasta.Potensi Yang Dimiliki Masyarakat Desa Danda Jaya yang bisa dikembangkan adalah berupa Pertanian, Perkebunan (jeruk, rambutan, nenas, karet) dan lain-lain.

Adapun dari sektor pendidikan yang ada di Kecamatan Rantau Badauh Kabupaten Barito Kuala ini cukup maju, hal ini terlihat dari maraknya proses belajar-mengajar dan tersedianya sarana pendidikan dan yang cukup banyak untuk mencetak sumber daya yang berkualiatas dalam wilayah Kecamatan Rantau Badauh Kabupaten Barito Kuala. Kecamatan Rantau badauh memiliki bebarapa sarana/lembaga pendidkan negeri yang terdiri dari empat sekolah dasar, satu sekolah menengah pertama dan satu sekolah menengah atas. Untuk mencetak sumber daya yang berkualitas tidak hanya diperlukan sarana pendidikan yang cukup, tetapi juga diperlukan guru yang memiliki profesionalisme yang baik. Guru sebagai ujung tombak dalam dunia pendidikan, dituntut untuk senantiasa tanggap dan peka terhadap berbagai pembaharuan yang terjadi di sekelilingnya. Tugas guru untuk senantiasa meningkatkan wawasan keilmuan dan meningkatkan kualitas pendidikannya, sehingga apa yang disampaikan oleh guru kepada siswa bukan hal yang kadaluwarsa. Dengan demikian, guru harus mampu mengikuti pesatnya perkembangan ilmu pengetahuan, teknologi dan informasi. Pesatnya perkembangan teknologi komputer dan informasi baik secara hardware maupun software, membuat guru harus dapat menyikapinya dengan bijak. Sebagian besar guru belum memanfaatkan teknologi komputer untuk proses pembelajaran, misal 
untuk membuat media pembelajaran sederhana berbasis computer untuk kegiatan pembelajaran.

Melihat kondisi seperti diatas maka salah satu langkah yang perlu diambil adalah dengan peningkatan profesionalisme guru dengan melakukan pelatihan komputer berbasis user needs assistment

Target dan luaran yang diharapkan pada kegiatan pengabdian pada masyarakat ini berupa: meningkatnya kemampuan guru dalam membuat media pembelajaran berbasis komputer.

\section{Landasan Teori}

Pembelajaran adalah proses interaksi peserta didik dengan pendidik dan sumber belajar pada suatu lingkungan belajar. Proses pembelajaran dialami manusia sepanjang hayat dan berlaku dimanapun dan kapanpun. Pembelajaran menurut Martinis Yamin (2007: 75), proses pembelajaran yang dilakukan dalam kelas merupakan aktivitas mentransformasikan pengetahuan, sikap, dan keterampilan. Pendapat tersebut dapat mengandung arti bahwa proses transfer pengetahuan, sikap, dan keterampilan dilakukan oleh setiap individu yang belajar. Menurut Dimyati dan Mudjiono (Syaiful Sagala, 2011: 63) pembelajaran adalah kegiatan guru secara terprogram dalam desain instruksional, untuk membuat belajar secara aktif, yang menekankan pada penyediaan sumber belajar.

Pembelajaran adalah pemberdayaan potensi peserta didik menjadi kompetensi. Kegiatan pemberdayaan ini tidak dapat dikatakan berhasil bila tidak ada orang atau individu. Dalam Undang-Undang No. 20 Tahun 2003 Tentang Sistem Pendidikan Nasional pasal 1 ayat 20 menyatakan bahwa pembelajaran diartikan proses interaksi peserta didik dengan pendidik dan sumber belajar pada suatu lingkungan belajar.

Pembelajaran menurut Nasution (2005) yang dikutip oleh Sugihartono (2007: 80) adalah aktivitas mengatur lingkungan belajar dengan sebaik mungkin dan menghubungkan dengan peserta didik sehingga terjadi proses belajar. 9 Konsep pembelajaran menurut Biggs (1985) yang dikutip oleh Sugihartono (2007: 80) dibagi dalam 3 pengertian yaitu:

a. Pembelajaran secara kuantitatif berarti guru mengajarkan pengetahuan yang dikuasai sehingga siswa tertular pengetahuan tersebut.

b. Pembelajaran secara institusional berarti guru mampu dalam mengadaptasi teknik mengajar sehingga pembelajaran berjalan efisien.

c. Pembelajaran secara kualitatif berarti upaya guru untuk melibatkan siswa dalam pembelajaran sehingga terjadi suasana belajar yang efektif dan efisien.

Dari teori yang ada di atas dapat diambil kesimpulan bahwa setiap pembelajaran diperlukan usaha dan optimalisasi kondisi lingkungan agar terbentuk suasana belajar.

Kata media berasal dari bahasa Latin yang berarti perantara atau pengantar. Menurut Azhar Arsyad (2011: 3) memaparkan bahwa media berasal dari bahasa Latin yaitu medius yang secara harfiah memiliki arti tengah, perantaraatau pengantar.Media dalam bahasa Arab berarti perantara atau pengantar pesan dari pengirim kepada penerima pesan. 
Media adalah komponen sumber belajar yang mengandung materi instruksional di lingkungan peserta didik yang dapat merangsang peserta didik untuk belajar. Azhar Arsyad (2011: 5) menyatakan bahwa istilah media seringdikaitkan dengan kata teknologi yang berasal dari bahasa Latin tekne (Bahasa Inggris art) dan logos yang dalam bahasa Indonesia berarti ilmu.

Penggunaan media pembelajaran dalam proses belajar mengajar mempunyai bagian yang penting demi mewujudkan proses kegiatan pembelajaran yang efektif dan mendapatkan hasil yang baik. Gerlach dan Ely (1971) dalam Arsyad Azhar (2011: 3) mengatakan bahwa media diartikan secara luas adalah manusia, materi dan kejadian yang membuat siswa mampu memperoleh pengetahuan, keterampilan atau sikap. Sedangkan menurut Fleming (1987) dalam Arsyad Azhar (2011: 3) media menunjukan fungsi atau perannya yaitu mengatur hubungan yang efektif antara dua pihak utama dalam proses belajar siswa dan isi pelajaran. Gagne menyatakan bahwa media adalah berbagai jenis komponen dalam lingkungan siswa yang dapat merangsang untuk belajar. Azhar Arsyad (2011: 2-3) menyatakan bahwa media adalah bagian yang tidak terpisahkan dari proses belajar mengajar demi tercapainya tujuan pendidikan pada umumnya dan tujuan pembelajaran di sekolah pada khususnya.

Menurut Azhar Arsyad (2011: 15) fungsi utama dari media pembelajaran adalah sebagai alat bantu mengajar yang turut mempengaruhi iklim, kondisi, dan lingkungan belajar yang ditata dan diciptakan. Menurut Hamalik yang di kutip Azhar Arsyad (2011: 15) mengemukakan bahwa pemakaian media pembelajaran dalam proses belajar mengajar dapat membangkitkan keinginan dan minat yang baru, membangkitkan motivasi dan rangsangan kegiatan belajar, dan bahkan membawa pengaruh-pengaruh psikologis terhadap siswa. Menurut Kemp dan Dayton (1985) yang dikutip Azhari Arsyad (2011: 19) media pembelajaran dapat memenuhi tiga fungsi utama apabila media digunakan untuk perorangan, kelompok, atau kelompok pendengar yang besar jumlahnya, yaitu 1) memotivasi minat atau tindakan, 2) menyajikan informasi, dan 3) memberi instruksi.

Penggunaan media pembelajaran dapat memberikan kemudahan bagi peserta didiki untuk memahami dan menyerap materi pelajaran yang diajarkan. Fungsi-fungsi dari penggunaan media pembelajaran menurut Asnawir dan Usman (2002: 24), yaitu: (1) memudahkan belajar mengajar, (2) memberi pengalaman nyata, (3) belajar lebih menyenangkan dan tidak membosankan, (4) mengaktifkan semua indera siswa, (5) menarik perhatian siswa. Media pembelajaran dapat dijadikan sebagai alat bantu guru untuk memudahkan dalam menyampaikan materi ajar kepada peserta didik. Media pembelajaran diharapkan dapat memberi pengalaman nyata bagi peserta didik dalam memahami materi yang disampaikan oleh guru. Adanya media pembelajaran dapat pula untuk menarik perhatian dan minat peserta didik dalam belajar.

Menurut Sudjana dan Rivai yang dikutip Azhar Arsyad (2003: 24) mengemukakan manfaat dari media pembelajaran dalam proses belajar mengajar, yaitu: (1) menumbuhkan motivasi atau minat belajar mahasiswa, (2) memudahkan siswa dalam memahami dan menguasai materi, (3) menambah variasi guru dalam mengajar, (4) menambah keaktifan siswa dalam pembelajaran, (5) mengurangi penggunaan bahasa, (6) membantu menyederhanakan proses pembelajaran, (7) 
menyamakan persepsi mahasiswa, dan (8) membuat proses belajar lebih menarik dan interaktif.

Dari beberapa manfaat media pembelajaran di atas diambil kesimpulan bahwa media pembelajaran dapat menarik perhatian lebih dari peserta didik dan mampu meningkatkan motivasi untuk belajar. Media pembelajaran menjadikan metode pembelajaran akan lebih bervariasi dengan banyak melibatkan peserta didik untuk ikut aktif dalam proses pembelajaran sehingga tidak terjadi kebosanan pada peserta didik.

\section{METODE KEGIATAN}

\section{Pendekatan Masalah}

Kepedulian Lembaga Perguruan Tinggi kepada masyarakat guru-guru dalam rangka meningkatkan profesionalisme guru dan kualitas pendidikan adalah tinggi, ini merupakan Tri Dharma Perguruan Tinggi. Untuk merealisasikan program tersebut diperlukan suatu rencana. Program pengabdian pada masyarakat yang dilaksanakan dalam kegiatan ini adalah "Pelatihan Pembuatan Media Pembelajaran Berbasis Komputer Di Sekolah Menengah Pertama Kecamatan Rantau Badauh Barito Kuala"

Materi pelatihan ini menitikberatkan pada pemanfaatan komputer untuk membuat media pembelajaran sederhana untuk meningkatkan kemampuan dan keprofesionalan guru sehingga tercapai mutu pembelajaran yang baik. Pelaksanaa kegiatan ini didukung oleh para staf pengajar Program Studi Alat Berat Politeknik Negeri Banjarmasin.

\section{Metode Kegiatan}

Kegiatan pelatihan yang diselenggarakan menggunakan metode survei, ceramah, praktek pelatihan dan diskusi - konsultasi. Survei dilakukan dengan menyebarkan angket 'user need assesment' kepada guru sekolah untuk mendapatkan data jenis dan kebutuhan guru dalam penguasaan ketrampilan komputer yang paling dibutuhkan. Penguasaan ketrampilan komputer dikategorikan dalam pendukung proses pembelajaran, pembuatan media pembelajaran.

Metode ceramah, praktek pelatihan dan diskusi-konsultasi dilakukan selama kegiatan pelatihan komputer. Secara rinci metode yang dilakukan adalah sebagai berikut:

1. Ceramah penjelasan diberikan kepada peserta dalam hal pengeksplorasian lebih dalam terhadap fitur-fitur perangkat lunak bantu yang dapat digunakan untuk pengolahan pengolahan media pembelajaran.

2. Penjelasan disertai langsung dengan praktek pelatihan pembuatan media pembelajaran sederhana.

3. Ceramah penjelasan disertai praktek dilakukan untuk memberikan wawasan kepada peserta tentang pencarian informasi yang efektif dengan menggunakan tip dan trik pembuatan media pembelajaran. 
4. Selama pelatihan peserta difasilitasi dalam melakukan diskusi-konsultasi untuk membahas permasalahan yang timbul dalam pembuatan media pembelajaran sederhana.

5. Pada akhir pelatihan diedarkan angket evaluasi untuk mengetahui kepuasan peserta terhadap pelatihan yang diselenggarakan dan menjaring saran-saran untuk tindak lanjut pelatihan.

\section{HASIL DAN PEMBAHASAN}

Pelatihan ini dilaksanakan selama bulan Agustus sebanyak 8 (delapan) kali sesi pertemuan. Aplikasi yang digunakan pada pelatihan ini menggunakan Microsoft PowerPoint 2013.

Pelatihan diikuti oleh 23 orang guru dari 3 Sekolah Menengah Pertama di Kecamatan Rantau Badauh Kabupaten Barito Kuala, yaitu SMPN 2 Rantau Badauh, SMPN 3 Rantau Badauh dan SMPN 4 Rantau Badauh.

Pada sesi pertama diberikan pengenalan jendela kerja Microsoft PowerPoint, hal ini dikarenakan berdasarkan angket terdapat beberapa Guru yang belum begitu mengenal Microsoft PowerPoint 2013. Sesi pertemuan kedua diisi dengan cara membuat design slide PowerPoint. Sesi pertemuan ketiga diberikan pengetahuan tentang Custom Animation. Pada sesi pertemuan keempat diberikan bagaimana proses pembuatan Grafik dan SmartArt. Sesi pertemuan kelima diberikan bagaimana cara menambahkan audio dan video. Pada sesi pertemuan keenam diberikan cara membuat slide master, hyperlink hingga membuat action. Selanjutnya pada sesi pertemuan ketujuh diajarkan bagaimana membuat slide pembelajaran interaktif. Kemudian pada sesi pertemuan kedelapan disampaikan bagaimana membuat video kreatif di PowerPoint. Setiap sesi diberikan terlebih dahulu teori kemudian dilanjutkan praktek.

Kegiatan pelatihan ini telah meningkatkan kemampuan guru-guru dalam membuat media pembelajaran berbasis komputer dalam hal ini menggunakan Microsoft PowerPoint, baik sebagai media presentasi maupun pembuatan soal interaktif.

Berikut contoh antar muka media pembelajaran dan soal untuk ujian yang telah dibuat :

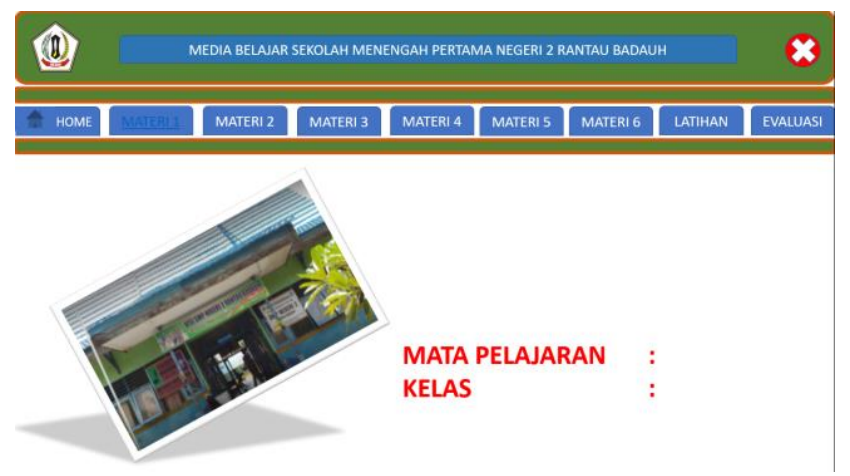

Gambar 1. Contoh Antar Muka Media Pembelajaran 


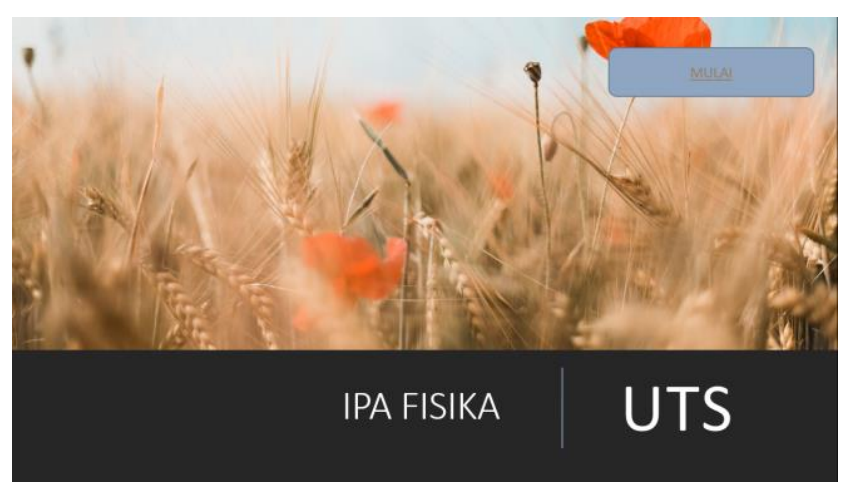

Gambar 2. Contoh Antar Muka untuk Soal UTS

\section{KESIMPULAN}

Setelah selesainya kegiatan pengabdian masyarakat ini yaitu berupa Pelatihan Pembuatan Media Pembelajaran Berbasis Komputer didapatkan terjadinya peningkatan pengetahuan dan kemampuan guru dalam membuat media pembelajaran berbasis komputer dalam hal ini menggunakan Microsoft PowerPoint.

\section{UCAPAN TERIMA KASIH}

Ucapan terima kasih yang sebesar-besarnya kepada seluruh pihak yang telah membantu terlaksananya kegiatan pengabdian masyarakat ini dari tahap pengusulan, pelaksanaan, sampai dengan penyelesaian laporan. Kagiatan Pengabdian Kepada Masyarakat ini tidak dapat terlaksana dengan baik tanpa bantuan dan dukungan dari berbagai pihak, diantaranya Pusat Penelitian dan Pengabdian Masyarakat (P3M) Politeknik Negeri Banjarmasin yang telah memfasilitasi khususnya dalam hal pendanaan, Bapak Supiyani S.Pd., MM, Kepala Sekolah Menengah Pertama Negeri 2 Rantau Badauh berikut seluruh guru dan staff, yang telah bersedia menjadi mitra tempat pelaksanaan kegiatan Pengabdian Masyarakat dan membantu selama kegiatan, Ibu Yayuk Supriawildarti Kepala SMPN 4 Rantau Badauh, dan seluruh guru yang telah berpartisipasi sebagai peserta dalam kegiatan Pengabdian Masyarakat ini.

\section{DAFTAR PUSTAKA}

Ahmad, F., 2012., Peningkatan Kualitas Sumber Daya Manusia Masyarakat Perkampungan Kumuh Banjir Kanal Timur Melalui Keterampilan Komputer <http://ahmadfakhruroji.blogspot.com/2012/08/>

Arsyad, A., 2002. Media pembelajaran, edisi 1. Jakarta: PT. Raja Grafindo Persada, 36.

Muhson, A., 2010. Pengembangan media pembelajaran berbasis teknologi informasi. Jurnal Pendidikan Akuntansi Indonesia, 8(2). 
Sadiman, A.S., 2009. Media Pendidikan pengertian, pengembangan dan pemanfaatannya. Jakarta: PT. Raja Grafindo Persada.

Asnawir, M., 2002. basyiruddin Usman. Media Pembelajaran. Padang: Ciputat Pers.

Arsyad, A., 2011. Media Pembelajaran. Jakarta: Raja Grafindo Persada.

Pribadi, B.A., 2009. Model desain sistem pembelajaran. Jakarta: Dian Rakyat, 35.

Hamalik, O., 1994. Media Pendidikan, cetakan ke-7. Bandung: Penerbit PT. Citra Aditya Bakti.

Niswatul Lutviani. 2007. Penggunaan Media Komputer Untuk Meningkatkan Kualitas Pembelajaran Pendidikan Agama Islam Di Smp Negeri 1 Selopuro Blitar

Nasution Inom, 2014.Peranan Guru Profesional Dalam Mendukung Peningkatan Mutu, <http://sumut.kemenag.go.id/file/file/TULISANPENGAJAR/vode1364669747.pdf)>

Andayani, S., Hernawati, K. and Setyaningrum, W., 2007. Upaya Meningkatkan Profesionalisme Guru-Guru Sekolah Dasar Di Daerah Istimewa Yogyakarta melalui Pelatihan Komputer Berbasis User Needs Assesment. Universitas Negeri Yogyakarta. 